\title{
Ecological patterns of fish distribution in the Slave River Delta region, Northwest Territories, Canada, as relayed by Traditional Knowledge and Western science
}

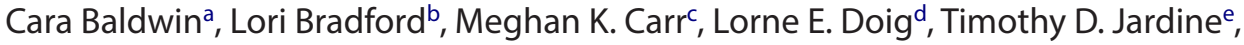 \\ Paul D. Jones ${ }^{e}$, Lalita Bharadwaj ${ }^{b}$ and Karl-Erich Lindenschmidt ${ }^{c}$

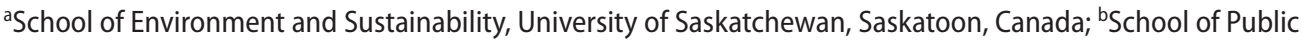 \\ Health, University of Saskatchewan, Saskatoon, Canada; 'Global Institute for Water Security, University of \\ Saskatchewan, Saskatoon, Canada; ${ }^{\mathrm{d} T o x i c o l o g y}$ Centre, University of Saskatchewan, Saskatoon, Canada; \\ eToxicology Centre and the School of Environment and Sustainability, University of Saskatchewan, Saskatoon, \\ Canada
}

\begin{abstract}
Indigenous community members along the Slave River in Canada have voiced their concerns for the health of ecosystems under pressure from resource extraction, hydroelectric development and global climate change. We present a test case of traditional knowledge and scientific results about the spawning and migration patterns of fish in the Slave River and Delta. This dual knowledge system approach elucidates the broader connectivity of local study regions and can improve monitoring programmes by extending beyond the usual context/confines of the present or recent past, increasing the spatial and temporal range of system information.
\end{abstract}

\section{ARTICLE HISTORY}

Received 9 October 2016

Accepted 15 February 2017

\section{KEYWORDS}

Cumulative effect monitoring; environmental management; fish habitat; fish migration; traditional knowledge; Western science

\section{Introduction}

The Slave River and Slave River Delta (SRD) make up a socially and biologically diverse ecosystem in which animals, plants, birds, fish and water play important roles in the lives of local indigenous peoples (Pembina Institute, 2016). Communities along the Slave River, such as Fort Smith and Fort Resolution, have diverse economies including federal, territorial and indigenous governments, educational and research institutes, resource extraction industries, tourism ventures, and traditional ways of life. Members of these communities have for some time expressed concern about cumulative environmental impacts from upstream resource extraction, hydroelectric development, agriculture, and pulp and paper mills, as well as global climate change (Culp, Cash, \& Wrona, 2000; Wolfe et al. 2007; Pembina Institute 2016). More recently, collaborative research partnerships have formed to facilitate the opportunity for the local community to address their concerns about environmental changes via a community-based monitoring programme (Canadian Water Network, 2015). One key question 
in this programme concerns the safety of fish for consumption. Given the migratory nature of fish in this region, an important step in answering this question is to better understand basic fish ecology to allow assessment of changes in their abundance and quality, and when and where they might be potentially exposed to contaminants.

The Slave River and the SRD support a diverse fish community of over 31 different species (as summarized by Tallman, Howland, Low, Tonn, \& Little, 2005). Common species of interest include inconnu (Stenodus leucicthys), lake whitefish (Coregonus clupeiformis), burbot (Lota lota), walleye (Sander vitreus), northern pike (Esox lucius), goldeye (Hiodon alosoides), longnose sucker (Catostomus catostomus), lake trout (Salvelinus namaycush), white sucker (Catostomus commersonii) and flathead chub (Platygobio gracilis). Little current information exists on population sizes and status of these species in the Slave River and SRD (Tallman, Tonn, \& Howland 1996b; Mackenzie River Basin Board, 2004; Working Group on General Status of NWT Species, 2011). Based on the most recent report on the status of wild species in the Northwest Territories (NWT) (Working Group on General Status of NWT Species, 2011), populations of lake whitefish, lake trout, northern pike, burbot and sucker are considered secure, meaning their populations are stable or increasing and limited threats to populations and distributions exist. In contrast, inconnu may be at risk, and walleye are sensitive. Species that may be at risk are facing rapid population decline and/or rapid decline in distribution and are ideal candidates for a detailed risk assessment, while sensitive species are not at risk of extinction or extirpation but face moderate population decline and/or moderate decline in distribution and may require protection to prevent their becoming at risk. Characterizing the habitat regions of fish species provides valuable information that can contribute to the development of monitoring programmes, stock assessments and remediation efforts in the SRD region.

Traditional foods systems were, and to some extent remain, fundamental to the survival of indigenous communities in Canada. Traditional foods, sometimes referred to as country foods, consist of animal and plant species harvested from the natural environment by hunting, trapping, fishing, and collecting eggs and plants or berries. These activities contributed to the fitness and health, cultural identity and values, knowledge of the land, and way of life of indigenous people. Whereas traditional foods once made up $100 \%$ of a daily diet, recent studies list traditional foods as being eaten, on average, once per day (Wein \& Freeman, 1995; Wein \& Wein, 1995). Country foods make up 3-33\% of daily energy intake in the Northwest Territories (Collings, Marten, Pearce, \&Young, 2016; Donaldson et al., 2010; Sheehy et al., 2015), with traditional meats (mammals, fish, birds) making up one-third of total animal consumption (Nakano, Fediuk, Kassi, \& Kuhnlein, 2005). Sharing traditional foods is an important social interaction among indigenous peoples (Collings et al., 2016). Fish in particular are of value to indigenous people living in the north, but are also of concern because of reported tissue levels of contaminants and possible amplification of these contaminants up trophic levels (Braune et al., 1999; Lockhart et al., 2005). Nakano et al. (2005) reported that fish makes up about $11 \%$ of children's diets in five communities in the Canadian Arctic and Subarctic.

Monitoring of cumulative effects on the fish species and aquatic ecology of the SRD region is important because of the continued practice of commercial and subsistence harvesting of fish for consumption as a staple food and a source of income. In the past, monitoring of fish species occurred as a part of government-sponsored basin-level research (e.g. Northern River Basins Study) and as a precursor to planned upstream industrial and energy-production projects (e.g. Slave River Hydro Study, Pembina Institute, 2012). Given ever-increasing 
development in the southern catchments of northern river systems and continued development in Canada's north, it is important that cumulative effects monitoring integrate all available data to support the health, well-being and engagement of northern populations.

\section{Traditional knowledge has a place in cumulative effects monitoring}

This article uses the definition of traditional knowledge (TK) brought forth by Berkes, Colding, and Folke (2000): 'knowledge [and] practices ... that describe the relationships of living beings with one another and with their physical environment which ... has been handed down through generations by cultural transmission'. It is also important to note that TK refers to a collection of data that was generated within a community, and makes sense to local people because of the value systems and cosmological contexts of the community in which it is used (Gallagher, 2003; Houde, 2007). Though TK might complement data collected through conventional scientific methods, TK is a valid knowledge system in its own regard. TK extends beyond political (i.e. provincial and municipal) and ecological (i.e. watershed) boundaries through its transmission across time and through transient populations. It is both intergenerational in nature (Dei, 2000) and cumulative across regions and cultures (Iseke-Barnes, 2003).

While few recent surveys of spawning and migration patterns were found for the Slave River and Delta in peer-reviewed and grey literature, TK of these patterns is rich among community elders and local harvesters. This article seeks to provide a more complete picture of the ecological changes of fish species and distribution of spawning and rearing habitats in the Slave River and SRD through blending knowledge systems. It thus contributes to recent debate about combining spatially diverse and temporally varied data for holistic understanding of socio-ecological systems (Armitage, Berkes, Dale, Kocho-Schellenberg, \& Patton, 2011; Leys \& Vanclay, 2011; Smith \& Sharp, 2012; Sutherland, Gardner, Haider, \& Dicks, 2014). In particular, Nash (2014) points out that defining which scales temporal and spatial ecological data are drawn from for cumulative effects assessments can be problematic for decision making because of ecological principles such as connectivity via dispersal, and migratory practices of fish species.

The goal of the project was to support holistic learning about the spawning and migration patterns of fish in the Slave River and SRD through the blending of Western science (WS) and TK. This was achieved by undertaking four main tasks: (1) literature review of fish habitat and migration in the SRD region; (2) interviews with elders and local people with a long history of living off the land and harvesting fish in the Slave River and Delta; (3) comparing and blending findings of the literature review and TK interviews; and (4) gaining a holistic understanding of changes to fish habitat in the Slave River and Delta. The article begins with describing the study area, then moves to describe the approach and results from each task, before it concludes by blending the data and providing recommendations for cumulative effects monitoring. In this article, TK evidence illustrated the need for rethinking measurement and decision-making boundaries during cumulative effects monitoring. The blending of TK and WS extended our understanding of this system beyond typical measurement boundaries, for a clearer indication of cumulative effects on fish populations in the Slave River and Delta. 


\section{Methods}

\section{Study area}

The Slave River begins at the confluence of the Riviére des Rochers and the Peace River in Northern Alberta and flows for approximately $420 \mathrm{~km}$ until entering Great Slave Lake (Figure 1). The Slave River draws its water from a total catchment area of roughly $600,000 \mathrm{~km}^{2}$, with the Peace River contributing as much as $77 \%$ of flow in spring, decreasing to $42 \%$ in the fall (English, Stone, Hill, \& Wolfe, 1996). The Slave also receives flow from the Athabasca River and Lake Athabasca via north-flowing channels of the Peace-Athabasca Delta. The Slave River has a mean annual flow of $3400 \mathrm{~m}^{3} / \mathrm{s}$ (Environment Canada, 2015). The W.A.C. Bennett Dam opened in 1968 on the Peace River in British Columbia, and it has altered the magnitude and timing of seasonal flows in the river, as presented in Figure 2. Post-dam flows reach an average peak of $5000 \mathrm{~m}^{3} / \mathrm{s}$ in June, decreasing to $2500 \mathrm{~m}^{3} / \mathrm{s}$ in December, compared

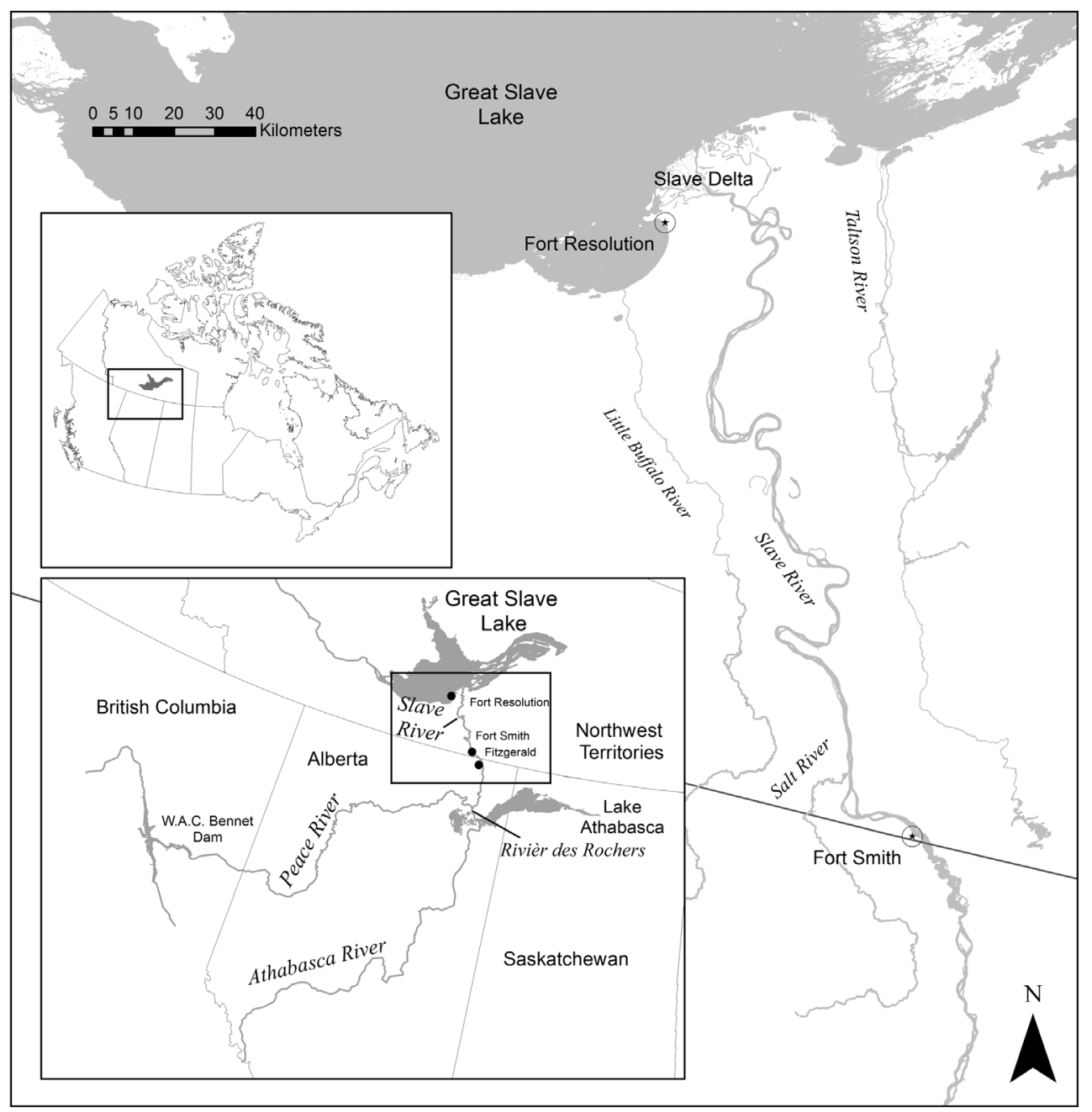

Figure 1. The Slave River Study Region, Northwest Territories, Canada. 


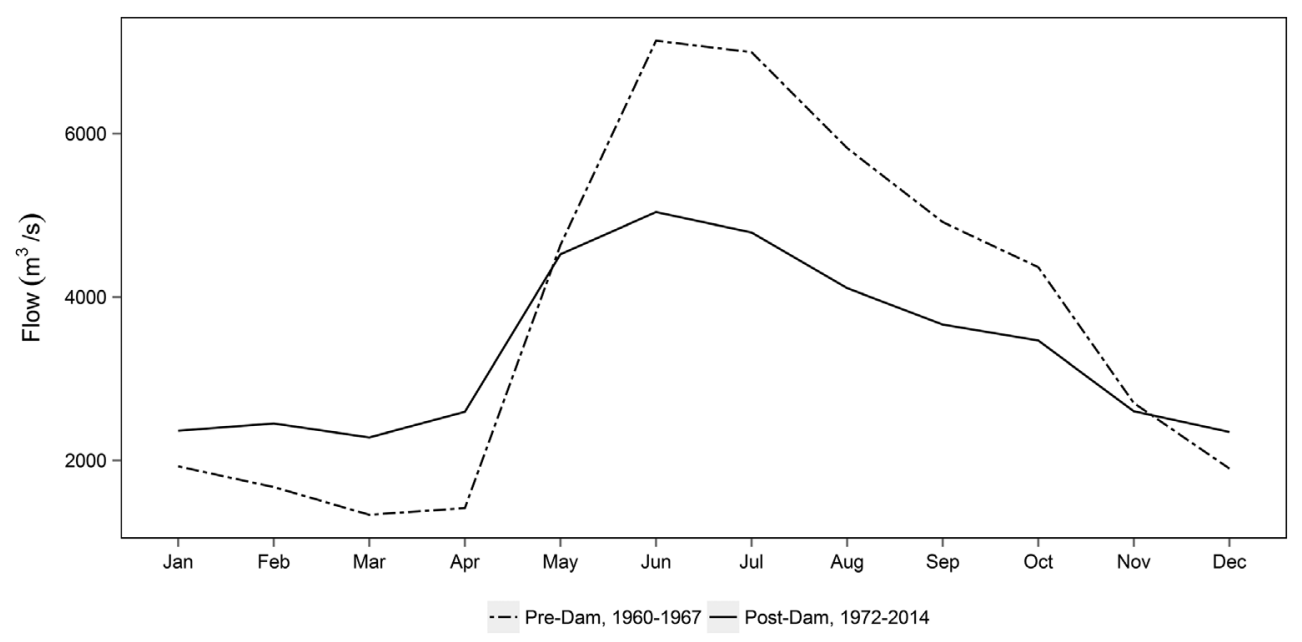

Figure 2. Mean annual flows of the Slave River at Fort Fitzgerald, Alberta.

to an average peak of $7000 \mathrm{~m}^{3} / \mathrm{s}$ in June, decreasing to $1200 \mathrm{~m}^{3} / \mathrm{s}$ in March, under pre-dam conditions (Figure 2). This change in flow regime is thought to affect the temporal flux and magnitude of sediment delivery to the SRD, decreasing sediment load by an estimated 33\% (English, Hill, Stone, \& Ormson, 1997). This may have implications for the transport of sediment-bound contaminants, the formation of different habitat features, and connectivity between different habitat areas in the SRD.

The Slave River and SRD provide habitat for a variety of plants and animals, such as migratory birds, fish, and aquatic furbearers (Bill, Crozier, \& Dennis, 1996; Pembina Institute 2016). The SRD has an area of $8300 \mathrm{~km}^{2}$, making it one of the three largest freshwater deltas in North America (Vanderburgh \& Smith, 1988). Figure 3 illustrates the four main channels of the SRD: the Resdelta, Middle, Steamboat and Nagle Channels. The biggest channel is the Resdelta Channel, which carries more than $80 \%$ of the total flow on average (Mollard 1981). This Slave River region has a dynamic and fluctuating climate, with a yearly average temperature of $-1.8^{\circ} \mathrm{C}$ at Fort Smith, and monthly averages ranging from $17.0^{\circ} \mathrm{C}$ in July to $-22.4^{\circ} \mathrm{C}$ in January.

In Fort Smith and Fort Resolution, community members' livelihoods include travel and harvest within the Slave River and Delta ecosystem. Many people rely on their interconnectedness with the river and delta for sustenance and livelihoods, including hunting, fishing and tourism operations. Thus, within the local indigenous communities there is recognition of the importance of sound environmental stewardship (Bill et al., 1996; Pembina Institute, 2016).

\section{Data collection: two knowledges, two approaches}

TK and WS differ in many ways. TK tends to be subjective and is typically collected using qualitative methods, while WS is quantitative and strives to be objective (Mazzocchi, 2006). TK systems arise from an intuitive and holistic worldview, whereas WS systems arise through the use of analytical and reductionist approaches (Houde, 2007; Mazzocchi, 2006; Rathwell, Armitage, \& Berkes, 2015). TK is context-dependent, in contrast to WS, which often separates 


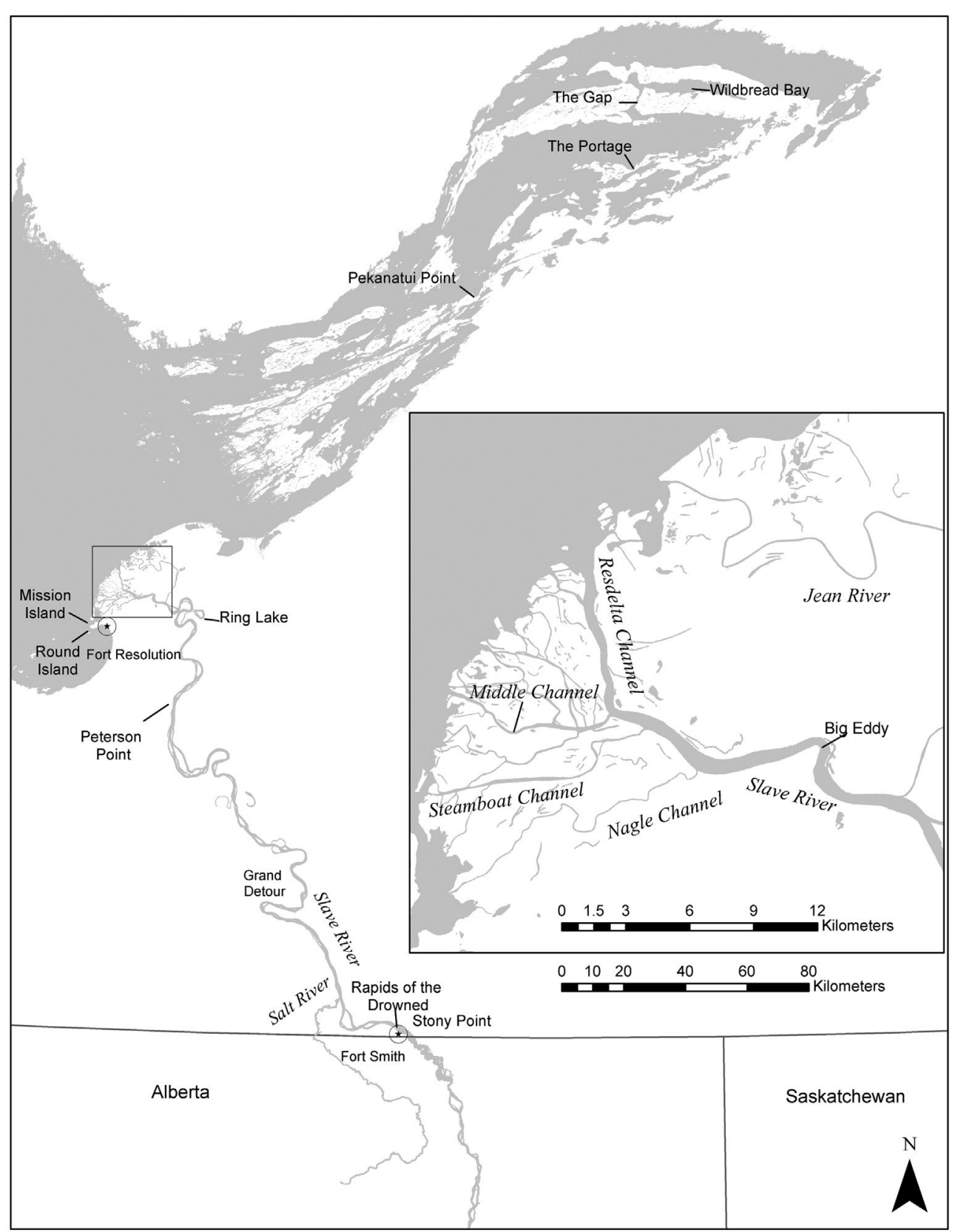

Figure 3. Detail of the Slave River Delta study area, NT, Canada. The study area includes Slave River Delta, Slave River, and the Eastern portion of Great Slave Lake. Locations mentioned in TK interviews are included.

its objects of study by placing them in controllable environments (Nakashima \& Roué, 2002). In some cases, TK is based on and includes spiritual elements. It is often transmitted orally from generation to generation, whereas WS has a tendency towards positivism and is based on written transmission (Nakashima \& Roué, 2002; Schauder, 1994). Furthermore, models of TK tend to incorporate the view that time is cyclical, while WS views time as linear (Freeman, 1992). Table 1 compares the use of TK and WS. 
Table 1. Comparison between use of traditional knowledge and Western science (adapted from Alaska Native Science Commission, n.d.; Bharadwaj, 2016).

\begin{tabular}{ll}
\hline Traditional knowledge & \multicolumn{1}{c}{ Western science } \\
\hline Lengthy acquisition & Rapid acquisition \\
Long-term wisdom & Short-term prediction \\
Powerful prediction in local areas & Powerful predictability in natural principles \\
Weak in predictive principles in distant areas & Weak in local areas of knowledge \\
Models based on cycles & Linear modelling as first approximation \\
Explanations based on examples, anecdotes, parables & Explanations based on hypothesis, theories, laws \\
Non-hierarchical & Hierarchical \\
Includes everything natural and supernatural & Excludes the supernatural \\
\hline
\end{tabular}

There is strong interest in approaching complex environmental problems with all available information to improve remediation efforts and decision making and policy creation (Brook \& McLachlan, 2008; Failing, Gregory, \& Harstone, 2007; Usher, 2000). In addressing the goal of this work, three objectives arose relating to the Slave River and Delta:

(1) Discover which areas of the delta, Slave River, and Great Slave Lake are used by SRD fish.

(2) Describe observed changes in historical areas and migration routes used by the fish in the Slave River and Delta.

(3) Identify locations impacted by change in the Slave River and SRD and associated effects on livelihoods. These objectives were chosen because of their potential to contribute to community concerns, including which locations along the river are most impacted, by which sources of pressures and/or contaminants, and which tributaries are the most important and need prioritization for any protection or remediation efforts.

A literature review was carried out to determine which fish species have been identified in the Slave River and the SRD, and their patterns of habitat use and migration. Though several studies of fish distribution in the study area were performed in the 1980s and 1990s, literature from recent years is lacking.

The First Nations Centered Research Framework was followed to conduct the TK data collection using semi-structured qualitative interviews (Bharadwaj, 2014). Established protocol (Centre for Aboriginal Culture and Education, n.d.; Council on Aboriginal Initiatives, 2012) was followed in conducting elder interviews. Interview guides were developed with the assistance of a local community coordinator. Interviews proceeded after a traditional offering was provided, blessing occurred, and the elder or local person indicated they were ready. Participants were given the opportunity to review transcripts after the interview and to add or delete elements if they wished. Transcripts were thematically coded (Boyatzis, 1998) by two members of the research team, and any codes related to fish and fish ecology were highlighted and compiled. The author team was then given the list of codes and supporting quotations to consider with the other results.

Data were gathered during 11 face-to-face interviews conducted in Fort Smith and Fort Resolution from April to November, 2014 (Bradford \& Bharadwaj, 2016). Recruitment was guided by a consultative process with First Nations and Metis Council members. A list of potential participants was provided to the researchers. Participants were contacted by phone or through random face-to-face encounters and conversations in the communities. A demographic representation of participants was not a goal. Participant selection, as guided by 
First Nations and Metis Council members, was based on past and current experience, knowledge, skill and practices of traditional food gathering. The interviews lasted from 45 minutes to three hours. Nine of the community members were male, and two were female. Community members ranged in age from 47 to 80 , with an average of about 67 years. Participants were resident in the two communities; however, across their lifespans they had travelled extensively, and as a group, had resided in at least seven town sites or other settlements in the South Slave region.

In the interviews, community members were asked to discuss changes in the Slave River and Delta. When discussing changes in the fish, they were asked to provide details about fish species and areas important for the life cycles of the fish. Participants were also shown several pictures and maps of the SRD region, ranging from the 1940s up to 2015. Participants used these maps to point out places of significance in relation to fish species, life cycles and fish changes they felt were important while they shared their stories. The interview transcripts underwent content analysis, and emerging patterns and insights related to fish species, habitat, life cycles and changes were categorized. For example, the community members were invited to share knowledge about overwintering and spawning habitats of fish species, locations of catches, and fish quality and quantity, as well as fish consumption preferences.

\section{Results}

\section{Literature review}

The main migratory fish species identified in the literature were lake whitefish and inconnu. These species migrate from Great Slave Lake through the SRD to feed and spawn in other areas. Lake whitefish have diverse habitat use patterns in relation to the Slave River, with Little (1997) identifying three different groups: (1) migratory whitefish that return to the river in the fall to spawn; (2) juvenile whitefish that are present and feeding in the river throughout the year; and (3) a small peak of adult whitefish that are found in the spring after ice break-up and that likely overwintered at their spawning grounds. The Rapids of the Drowned, near Fort Smith, is a known whitefish spawning site, and both the Resdelta Channel and the Salt River, a tributary $25 \mathrm{~km}$ downstream of Fort Smith, have been identified as important feeding and rearing areas for juvenile lake whitefish. Inconnu migrate from Great Slave Lake into the delta between August and September, with inconnu appearing at Fort Smith in the second week of August (Tallman, Tonn, \& Little, 1996c; Howland, Tallman, \& Tonn, 2000; Little, Tonn, Tallman, \& Reist, 1998). A telemetry study by Howland and colleagues (2000) followed inconnu tagged between August and October in the Slave River and found that all detections and recaptures of tagged fish occurred between the Rapids of the Drowned and the Salt River, suggesting that important spawning habitat is located within this reach. Catch-perunit-effort of inconnu declined substantially by the third week of October, and no inconnu were caught in the first week of December, suggesting that they had returned to Great Slave Lake, most likely deeper offshore areas, to overwinter. Inconnu captured and tagged in Great Slave Lake were also detected in the Buffalo River during spawning season (Howland et al., 2000). Inconnu summer and post-spawn feeding areas are concentrated around the mouths of spawning rivers (Slave, Hay, Buffalo) and the shallow south basin of the lake (DFO, 2013; Howland et al., 2000). 
The resident species (burbot, walleye, northern pike, goldeye, longnose sucker, white sucker and flathead chub) complete their life cycle within the river and delta but often migrate considerable distances along the river, possibly to preferred feeding or spawning areas (Little, 1997; Little, Tonn, Tallman, \& Reist, 1998). Species found in the Slave River and Delta during the open-water period included northern pike, flathead chub, walleye, goldeye, burbot, longnose sucker and trout-perch (Percopsis omiscomaycus). In the spring after ice break-up, juvenile northern pike are present in the delta and certain areas near Fort Smith, while adults are generally abundant near Fort Smith, where they are known to spawn. In some years adult pike in spawning condition have been observed congregating in the delta after break-up, suggesting that spawning may also occur there (Tallman, 1996). Juvenile pike have also been found to be abundant in the Salt River, a possible spawning location (Tallman et al., 2005).

Flathead chub, walleye and goldeye are all abundant in the Slave River in spring, likely due to spawning aggregations. Though there is no specific information on spawning locations for flathead chub or goldeye, they likely spawn in the Slave River, and they are known to be abundant in both the Slave River and Delta throughout the open-water season (Stewart, 1999; Tallman, 1996). Walleye are known to spawn at the Rapids of the Drowned, by Fort Smith, and may also use the Salt River for spawning. The East, Middle, Old Steamboat and Nagle Channels of the delta have been cited as important feeding and rearing areas for northern pike, flathead chub, burbot and small forage species (Stewart, 1999).

Burbot have not been as readily captured in the majority of existing studies, as they are not as vulnerable to gillnet capture as the other species. Burbot are relatively sedentary and are present in the Slave River, Slave Delta and Salt River throughout the year. Burbot spawning habitat has been identified in the Resdelta Channel and the lower reaches of the Slave River (Tripp, McCart, Saunders, \& Hughes, 1981). Longnose sucker are present in the SRD, Slave River and Salt River, while white sucker are found in the Slave River and Salt River (Tallman et al., 2005). Longnose spawn in the East, Middle, Old Steamboat and Nagle Channels (Stewart, 1999), and it has been suggested that they may also spawn at locations upstream in the Slave River (Tripp et al., 1981). Finally, trout-perch were present in high numbers in both the SRD and the Slave River. Minimal fish species distribution information is available for the ice-covered season, though it has been proposed that both adult pike and walleye overwinter in either Great Slave Lake or the delta, and most lake whitefish return to Great Slave Lake, though a substantial number of adults and juveniles overwinter in the Slave River (Tripp et al., 1981).

There was a reported seasonal pattern of harvesting fish species by the indigenous residents of Fort Smith (Little, 1997; Stewart, 1999). In May, they would harvest lake whitefish, northern pike, longnose suckers and goldeye. In mid-August, indigenous residents would harvest inconnu, some lake whitefish, and some northern pike (Stewart, 1999). In November and December, they would harvest burbot that would congregate under the ice (Little, 1997; Stewart, 1999). Overall, it was found that $50 \%$ of lake whitefish, $40 \%$ of northern pike, $10 \%$ of longnose sucker, $40 \%$ of inconnu and $30 \%$ of burbot caught were used for human consumption (Stewart, 1999). Table 2 provides a summary of fish species commonly identified in the literature review.

As part of a parallel study, community members of Fort Resolution requested water depth data for the SRD to corroborate observed changes in traditionally important areas and increase understanding of current depth patterns in the entire delta (Figure A1 in the 
Table 2. Fish species commonly identified in the literature review and traditional knowledge interviews.

\begin{tabular}{lccc}
\hline $\begin{array}{l}\text { Fish species identified in } \\
\text { the literature review }\end{array}$ & $\begin{array}{c}\text { Migratory or resident } \\
\text { species }\end{array}$ & $\begin{array}{c}\text { Identified in literature } \\
\text { 1. Burbot }\end{array}$ & $\begin{array}{c}\text { Identified in traditional } \\
\text { knowledge interviews }\end{array}$ \\
2. Flathead chub & Resident & $\checkmark$ & $\checkmark$ \\
3. Goldeye & Resident & $\checkmark$ & $\checkmark$ \\
4. Inconnu & Resident & $\checkmark$ & $\checkmark$ \\
5. Lake whitefish & Migratory & $\checkmark$ & $\checkmark$ \\
6. Longnose sucker & Migratory & $\checkmark$ & $*$ \\
7. White Sucker & Resident & $\checkmark$ & $\checkmark$ \\
8. Northern pike & Resident & $\checkmark$ & $\checkmark$ \\
9. Trout-perch & Resident & $\checkmark$ & $\checkmark$ \\
10. Walleye & Resident & $\checkmark$ & $\checkmark$ \\
\hline
\end{tabular}

*Community members did not specify species of sucker through traditional knowledge.

supplementary online data, at http://dx.doi.org/10.1080/07900627.2017.1298516). These data, although a snapshot in recent time, complement the existing literature on fish habitat in the SRD. In rivers, deeper pool habitats are associated with lower velocities and bed shear stress (Gharabaghi, Inkratas, Beltaos, \& Krishnappan, 2007), can be an important refuge for young-of-year and juvenile fish, and are desirable locations for overwintering (Scott \& Crossman, 1973). In lakes, ponds and river reaches with very low flow velocities the water column becomes stratified, with the warmest water at the bottom and the coldest, least dense water at the surface (Brown, Hubert, \& Daly, 2011). These characteristics make deep waters desirable habitat features in both the river reaches and Great Slave Lake. Results show that the Jean River, Nagle Channel and Steamboat Channel have similar characteristics, tending to be more shallow, straight and narrow than other channels, with the exception of occasional meanders in the Steamboat and Nagle Channels. The Middle Channel is similar to these channels but has areas of greater depth, while the Resdelta and Slave River Channels are much wider and deeper than all the others, particularly reaches between Big Eddy and the Jean River and the $5 \mathrm{~km}$ stretch downstream of the Middle Channel distributary (Figure A1).

\section{Traditional knowledge}

Community members noted much change in the Slave River and Delta region. Water levels in the SRD have been decreasing annually, and sandbar formation prevented access to preferred fishing locations. For instance, community members shared that, "We used to go through every channel the Slave River Delta had to offer, and now you can't go in probably sixty percent of them" (INT-1); and "Stony Point had good pickerel [but you] can't get there anymore because of the sandbar" (INT-5).

Community members were asked about fish quantity, and half of those interviewed said that there has been a decline in the amount of fish available for human consumption. A reduction in the number of fish, particularly northern pike, burbot, whitefish and lake trout, was commonly mentioned. For instance, some community members stated: "There's no fish! ... Before the dam, there was lots" (INT-2); and:

Back in the '40s, '50s, '60s, in the Taltson River, that's where the inconnus were.... When [inconnus] move, it's almost like thunder. They move, they stop.... People have nets and they go across, come back, it's full of inconnus. And after they put the [W.A.C.] Bennett Dam in, no inconnus. It just went down to nothing. (INT-1) 
Community members were asked about overwintering habitats of fish species. It was found that all fish species overwinter in deeper water in the delta and Resolution Bay, but the exact locations are unknown. It was also stated that inconnu, northern pike, burbot and the odd whitefish could be caught in the Slave River during the winter. For example, one community member said: "They all stay [in the delta]. All kinds of fish: white[fish], loche, [and] conie" (INT-11). (Loche, or loche maria, is a regional name for burbot.)

Community members were also asked about spawning habitats of fish species. They said that lake whitefish spawn in the Slave River, the Little Buffalo River, and the Jean River. Burbot, northern pike and goldeye spawn near the mouth of Nagle Channel. Burbot also spawn in the Slave River, and northern pike also spawn "across from the Portage" (Figure 3). Two people noted that the fall whitefish run starts later and later each year on the Taltson River. The inconnu spawning run happens in the fall, when they swim as far upstream as Fort Smith. Big Eddy on the Slave River was mentioned as a spawning location. Community members were asked about locations of catches. In the past, the community members would fish at several locations, which included the Gap, Jean River, Mission Island, Peterson's Point, Slave River, Stony Island, Stony Point, Taltson River and Wildbread Bay. In the 1970s and 1980s Ring Lake was a good spot to catch burbot. Many mentioned that the commercial fishery had greatly reduced the number of trout in Great Slave Lake, but noted that they have started to come back to Resolution Bay in recent years:

Just used to go out here, close to Mission Island here. We used to set hooks even in the summer, towards the fall, catch trout in a fish net. And in the ' 40 s, when the fisherman came to this lake, within a few years there was no trout. Not a thing until the last eight years - something around eight years - did they start to come back. (INT-8)

Today, community members still fish in the Slave River, Jean River and Taltson River. The Taltson River is reportedly good for walleye, the Jean River has burbot, and the Slave River is good for inconnu during spawning. However, they also catch fish at some different locations, such as Little Buffalo River, Pekanatui, and Round Island. One community member said: "The trout-perch is coming back. In the spring, I was just out on the dock there, about a kilometre and a half, every second I would catch a trout-perch" (INT-3).

Community members were asked about fish quality. Eight of the 11 participants experienced poor fish quality. The most common responses were about fish colour and poor-quality meat. For example, if the fish liver was not pink, community members would not consume it. When talking about poor-quality meat, one community member shared that: "My son's always fishing. He always gives me fish... You cook some of them and they're just mushy, like, soft" (INT-10).

Poor quality makes fish less desirable as a food source, and fear of contaminants has caused some people to intentionally reduce their consumption of fish and local delicacies like burbot liver:

When you cook, it changes colour. And you can tell even when you don't cook it. It's not, it's like a pink-white, and it changes when it's no good. Don't eat it if the liver is no good. And it happens regularly now. (INT-10)

Lastly, the community members were asked about fish consumption preferences. The community members preferred eating lake whitefish and walleye over other species, in an effort to avoid contaminants and also for their better taste.

Overall, community members believed that the SRD itself and the fish populations have changed. It was found that all fish species of interest overwinter in the delta and Resolution 
Bay, though no specific locations were mentioned. Timing of spawning differs for some species, and different fish species spawn in different areas than in the past. The community members also said that fish quality and quantity have been decreasing, and they preferred to consume lake whitefish and walleye.

\section{Blending published literature and traditional knowledge}

Given the findings of the data collection, there were two opportunities for synergism between the TK and WS data arising in this socio-ecological system. First, knowledge about the presence and movement of fish species in the system presented by both researchers and TK holders provides a more thorough understanding of change and adaptation in the SRD region. Seven fish species were mentioned in both the literature and the TK interviews: burbot, goldeye, inconnu, lake whitefish, northern pike, trout-perch, and walleye (Table 3). Though specific species were not differentiated, sucker were also mentioned in TK. While independently, each knowledge type offered information on a wider variety of fish species, it is encouraging to know that a diverse set of records exists for these seven species, which will provide greater detail on how changes in the river and delta have influenced fish populations. Second, knowledge of overwintering and spawning habitats of the seven fish species mentioned in both the literature and TK provide insights for environmental management. The map in Figure 4 provides an example of important habitat areas identified for inconnu (at risk) and walleye (sensitive), species which may require more detailed assessments and protection measures in the near future. The data revealed many similarities between the literature and the TK about fish species in the SRD region. Both stated that inconnu move from delta channels and Great Slave Lake into the Slave River to spawn in the fall and move as far upstream as Fort Smith. TK expanded upon this knowledge by revealing connections between Slave River inconnu populations and those in the adjacent Taltson River (Figure 4), which, like the Slave, has been affected by changes in water levels and flow regimes. Lake whitefish have more diverse habitat use patterns, as described in both the literature and TK. Both noted that whitefish spawn in the Slave River and Delta, and community members confirmed that some whitefish stay in the river and delta to overwinter, as they are regularly caught during the ice-covered months. TK mentioned more specific locations on the Slave River, different lakes within the Delta, and other tributaries used by fish, expanding on established habitat descriptions in the literature. For example, the Taltson River is a good place to find Walleye and "across from the Portage" was described as a spawning location for northern pike. This has implications for protecting flow regimes and water levels along the

Table 3. Spawning habitats of the different fish species.

\begin{tabular}{lll}
\hline Fish species & \multicolumn{1}{c}{ Spawning habitat from the literature } & \multicolumn{1}{c}{ Spawning habitat from TK } \\
\hline 1. Burbot & Resdelta Channel / Rapids of the Drowned & Slave River \\
2. Flathead chub & Slave River & N/A \\
3. Goldeye & Slave River & Nagle Channel \\
4. Inconnu & Rapids of the Drowned & Taltson River \\
5. Lake whitefish & Rapids of the Drowned & Little Buffalo River \\
6. Northern pike & Salt River, Slave River & N/A \\
7. Trout-perch & N/A & N/A \\
8. Walleye & Rapids of the Drowned, Salt River & Little Buffalo River \\
\hline
\end{tabular}




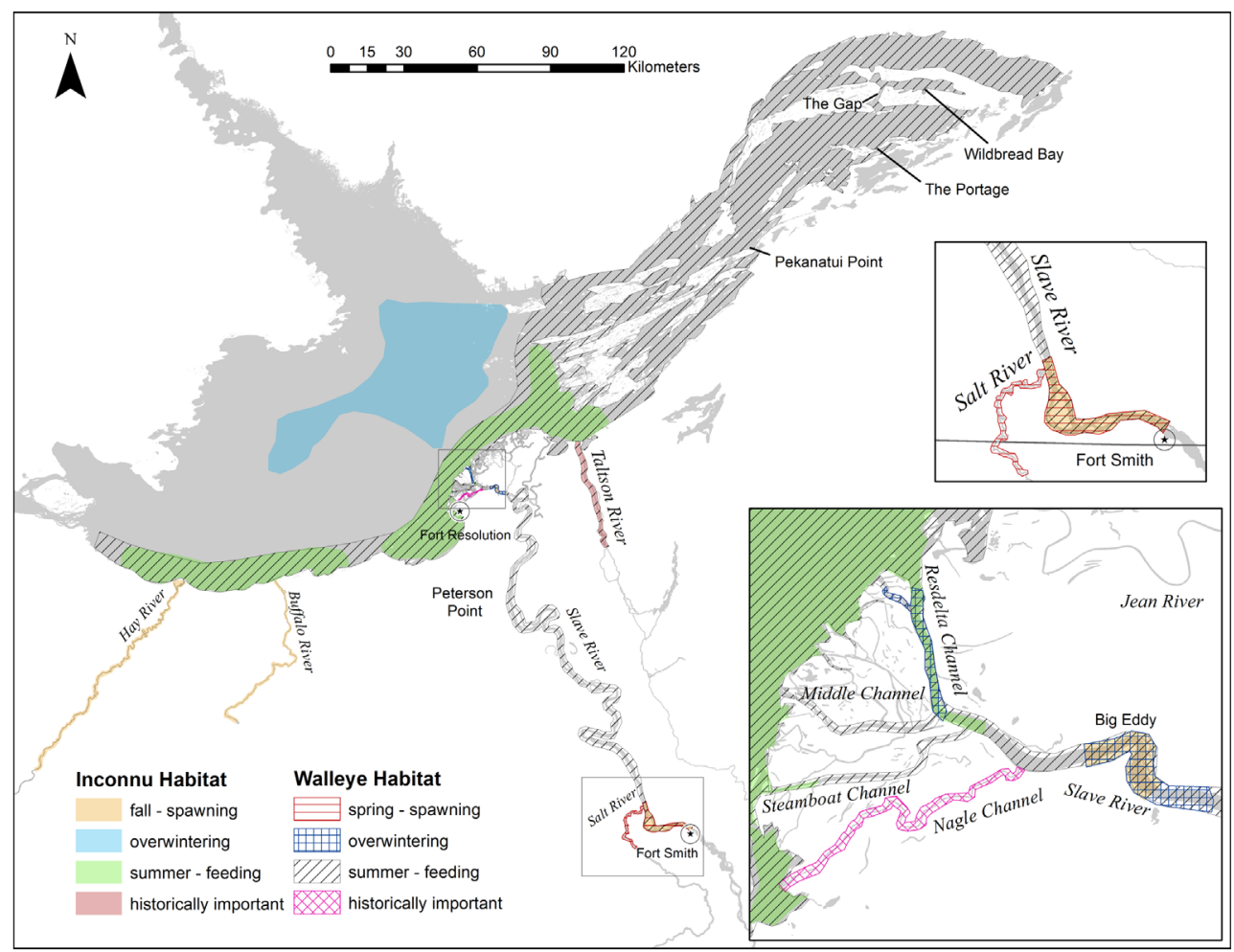

Figure 4. Inconnu and walleye habitat areas in the Slave River Delta region, NT, Canada, identified through the blending of WS and TK. This map is focused on information about inconnu and walleye populations that likely use the Slave River and SRD sometime within their life history and does not reflect the exact home range of these populations. Walleye are also known to overwinter in Great Slave Lake though no specific locations were identified in this study. Inconnu overwintering area is estimated as the deepest regions of Great Slave Lake.

river. Connectivity from the lake and delta to upstream locations in both the Slave and Taltson Rivers is important for successful spawning of several species.

There were also some differences between the literature and TK regarding spawning habitats. The Salt River was commonly mentioned in the literature but was not discussed by those interviewed. This may be because most of the individuals were currently living in the delta-focused Fort Resolution community and the Salt River tributary is near Fort Smith. There was far more TK about burbot than was available in the literature; this is likely because burbot are more readily caught with hooks under the ice and most studies in the literature were about netting during the open-water season. Information on goldeye spawning in the region was lacking, while community members shared that goldeye spawned in the mouth of the Nagle Channel. TK provided insight into the distribution and habitat use of these species, particularly spawning habitat. Table 3 shows the spawning habitats of the seven fish species.

Interview responses were considered alongside literature findings and new scientific results to address the fourth objective: blending scientific results and TK. We focus our efforts on finding synergy among results from Task 1 and 2 on the Nagle Channel locations due to 
the availability of data. Results of the depth survey found that the Nagle Channel and Steamboat Channel are the shallowest delta channels. Nagle Channel has been cited as an important feeding and spawning area for northern pike, flathead chub and burbot (Stewart, 1999), and community members reaffirmed that Nagle Channel is a goldeye spawning location and used to be a good location for catching certain kinds of fish. For example, one community member shared that they used to catch walleye in "Nagle Channel but now [it is] too shallow to get in there [because of] sandbars" (INT-6).

Despite this shift in habitat availability, these fish species are still present in channels of the Slave River (Ohiozebau et al., 2016), suggesting an adaptation to this physical environmental change. Community members noted that spawning dates were changing. The implication of this for baseline data establishment is that previous data from the literature review may be less relevant now for assessing cumulative impacts.

Literature review findings also demonstrate that the prey species of these fish are important for assessing cumulative impacts. For example, prey species may migrate and spend time in channels abandoned by larger species, but still contribute contaminants to higher trophic levels from channels with elevated contaminant concentrations. Ongoing studies have found that Nagle Channel has high mercury levels compared to other channels (Doig et al., submitted). Though the relationships between sediment contaminant levels, uptake by organisms, and transfer through aquatic food webs can be complex, it is possible that fish feeding on benthic food resources in this area face increased exposure to mercury due to elevated levels in sediments (Carr et al. 2017).

TK results state that community members historically caught inconnu in the Taltson River, likely during spawning migration, but that inconnu are no longer found in that river. The published literature cites inconnu spawning in the Slave River (Tallman et al. 1996a; Tallman, 1996; Little et al., 1998), though there are not enough data to infer whether fish spawning in the Slave River are a subpopulation distinct from that which historically spawned in the Taltson River, or whether there has been a shift in habitat use over time. This information suggests that maintaining access to spawning habitat in multiple tributaries may be important for sustaining inconnu stocks in Great Slave Lake. The benefit of TK is that the knowledge shared spans a wide variety of time and geography; for example, the participants were able to highlight how changes in the lake might influence fish stocks in the rivers, and vice versa. The benefit of uniting TK and WS in this project is that the data from both knowledge systems triangulate and provide mechanisms to explain changes in the socio-ecological system.

\section{Discussion}

The goal of this project was to support holistic learning about fish spawning and migration patterns in the Slave River and SRD and advance cumulative effects monitoring methods through the blending of WS and TK. This approach provides a means to track ecological change over the coming years and help support environmental management decision making in the face of cumulative impacts. When elders and local people indicate changes in fish spawning and migration, potentially brought on by changes in water level or site access, the approach taken by this study provides managers with: (1) broadly informed baseline data to assess environmental change; (2) insight into priority areas for focussed monitoring, protection or potential remediation; (3) information to support the protection of sensitive species under increased pressure; and (4) trend data regarding regional fish ecology. The 
variety of locations in which fish can be found within the Slave River and Delta and their complicated movements through this system highlight the need to consider the heterogeneity of fish habitat when monitoring complex river-delta-lake ecosystems. Inclusion of TK also provides opportunities for the voices of those living downstream of anthropogenic activities to be heard through the sharing of intergenerational local knowledge.

The first objective focussed on the different river and delta regions used by fish species. Again, both the literature and the community members reported species-specific use of certain areas for feeding and spawning. This information can assist in designing fish population monitoring studies, modelling ecosystems, and assessing access to fishing locations. Combined with contaminant distribution and bioavailability information, this knowledge can improve our understanding of contaminant exposure for fish and community members.

The second objective focused on reported and published changes in historical areas and migration routes used by fish. Community members have observed that water levels in the Slave River and Delta have been decreasing annually. They reported that low water levels affected the fish, and the livelihoods of people who support themselves by fishing and harvesting. Lower water levels meant that fish spawned less in the smaller channels and travelled less broadly in the delta than in the past. Fish harvesters are often now finding fish opportunistically instead of based on distribution patterns from the past and knowledge shared by their ancestors. Historical spawning harvests and fishing camps are not as common as in the past, and livelihoods have been affected by the reduced access and familiarity with fish spawning and migration cycles.

The third objective was to specify locations that have been impacted by changes in the Slave River and SRD area and the associated effects on livelihoods. The community members said that the Nagle Channel has been impacted by decreasing water levels. Sediment deposition and low water levels prevent community members from fishing in this channel, which was historically an important location for catching walleye. The timing of the fall whitefish migration has also changed, occurring later each year on the Taltson River. Such shifts have led to changes in fishing locations and timing. Half of those interviewed stated that there has been a decline in the amount of fish caught, and this has impacted those who rely on fishing for their livelihood and sustenance. The majority of community members have also observed a decrease in the quality of fish, and this has contributed to changes in diets. Given the historical importance of fish and other country foods to the people of the South Slave region, relevant, timely and accurate research results on ecological conditions are needed to inform local policy and support cultural adaptation.

This article shows how incorporating TK can contribute to defining the boundaries of cumulative effects monitoring in two ways. One, TK can nudge scientists to re-evaluate existing boundaries, for example, when and where to sample fish, and the importance of considering connectivity among fish stocks (e.g. adjacent rivers). Two, TK can describe how fish are adapting to ecological change, for example, changing spawning time and locations. Some fishing locations described in this project had changed from the baseline studies conducted 20-30 years ago, providing new information for Western scientists. Residents typically catch and consume burbot in the winter, yet scientists often sampled burbot and conducted analysis in other seasons. Fish sampling techniques typically used in WS (e.g. gill netting) likely contributed to far fewer burbot being caught, compared to the catches of local people and TK holders who ice-fished for burbot with single-hook lines. 
Habitat fragmentation is occurring in the Slave River and Delta, as evidenced by fish migration and population changes. Much as a linear power line divides the landscape and affects forest species composition (Bartzke, May, Bevanger, Stokke, \& Roskaft, 2014; Rioux, Savard, \& Gerick, 2013), channel depth in river and delta ecosystems likely influences the spatial distribution and accessibility of river and delta habitat and should be considered in cumulative effects monitoring programmes. Changes in total watershed volume or area could be considered as new indicators. Maps built through GIS and used during TK interviews can help clarify boundaries for sampling across a variety of water depths and channel access characteristics.

Cumulative effects monitoring with a combined WS and TK framework may provide benefits in several ways. It can help focus monitoring efforts and thus indirectly reduce the human, technical and financial costs of monitoring, and assist in the identification of possible health risks through appropriate site-specific exposure data. For example, understanding the species of fish consumed by groups within a particular community allows identification of potential human risk, the frequency of consumption, timing and seasonality of consumption, and human receptors (who eats what, when, how often, and how much). It informs monitoring of various site-specific ecosystem components for development of monitoring and risk-management regimes for current and emerging contaminants of concern.

Perceptions of risk are influenced by trust, transparency of relationships, and availability of information. Working together in co-monitoring efforts creates and builds relationships and potentially leads to trust, transparency and value in the monitoring programme but also the data derived from such a monitoring programme. These efforts may better inform risk communication, decision making and policy development. Cumulative effects monitoring programmes with a combined WS and TK framework may better inform long-term resource management decisions but also those decisions related to risk communication, mitigation and management, and perhaps even economic development, within specific communities and the general area of interest.

Future work could involve testing and assessing the application of a dual WS and TK approach in a cumulative effects monitoring framework. The approach could complement integrated water resources management systems, such as for the Okanagan Basin in British Columbia (Melnychuk, Jatel, \&Warwick Sears, 2016). Also, future work should seek knowledge from residents who fish the Salt River to supplement existing information. Future researchers working in this specific region could consider asking community members additional questions to increase the synergism of the findings. For example, to provide better linkage with contaminant data, researchers might ask community members what different fish species they consume. During this project more questions arose that could be asked in future studies: (1) What makes a specific site a good area for fish? (2) What are the most important tributaries for fish-rearing habitat? (3) Are community members concerned about specific sources of contaminants? (4) Where are these possible sources of contaminants? The answers to these questions could shed light on perceptions of cumulative environmental impacts and how they may be affecting the community members and various fish species in the Slave River and SRD area.

In summary, several fish species are of common interest to community members and researchers. Synergizing this information provided a broader understanding of environmental change in the SRD. Therefore, cumulative effects monitoring in the context of rivers and deltas should include both TK and WS, and in doing so, expand study boundaries beyond 
sampling local and regional populations of fish to considering connectivity and food-web relationships. Monitoring should include components such as channel depth and access for river and delta ecosystems. Scientists should expand sampling boundaries beyond those established in the literature, given the great spatiotemporal scale of environmental changes brought on through anthropogenic stressors.

\section{Conclusion}

TK and WS differ in many ways, and the findings of this project show how blending these sources of knowledge improves overall understanding of spawning and migration patterns of fish in the SRD region. Synergizing TK and WS aids in watershed management in several ways, including: (1) provision of baseline data for assessing environmental change; (2) identification of priority areas for protection or possible remediation; (3) information to support the protection of sensitive species under increased pressure; (4) expanded boundaries and indicators for cumulative effects monitoring; and (5) opportunities for the voices of those living downstream of anthropogenic activities to be heard through the sharing of local knowledge.

\section{Acknowledgements}

We would like to thank the community members from the Slave River and Delta Partnership and South Slave region who participated in this work. We gratefully acknowledge the funding provided by the Canadian Water Network's Slave Watershed Environmental Effects Programme and the Government of the Northwest Territories Cumulative Impacts Monitoring Program.

\section{Disclosure statement}

No potential conflict of interest was reported by the authors.

\section{Funding}

This work was supported by Government of the Northwest Territories [grant number CIMP 166 ].

\section{References}

Armitage, D., Berkes, F., Dale, A., Kocho-Schellenberg, E., \& Patton, E. (2011). Co-management and the co-production of knowledge: Learning to adapt in Canada's Arctic. Global Environmental Change, 21, 995-1004.

Bartzke, G. S., May, R., Bevanger, K., Stokke, S., \& Roskaft, E. (2014). The effects of power lines on ungulates and implications for power line routing and rights-of-way management. International Journal of Biodiversity and Conservation, 6, 647-662.

Berkes, F., Colding, J., \& Folke, C. (2000). Rediscovery of traditional ecological knowledge as adaptive management. Ecological Applications, 10, 1251-1262.

Bharadwaj, L. (2014). A framework for building research partnerships with first nations communities. Environmental Health Insights, 8, 15-25. doi:10.4137/EHI.S10869.

Bharadwaj, L. (2016). Indigenous Knowledge [Lecture notes]. Retrieved February 16, 2016, from https:// bblearn.usask.ca/

Bill, L., Crozier, J., \& Dennis S. (1996). A report of wisdom synthesized from the traditional knowledge component studies (Northern River Basins Study synthesis report no. 12). Retrieved February 24, 
2016, from http://www.total-epcanada.com/upstream/documents/Additional_Information/AIR_ July2010/Appendix_A_Report_of_Wisdom.pdf

Boyatzis, R. E. (1998). Transforming qualitative information: Thematic analysis and code development. Thousand Oaks, CA: Sage.

Bradford, L., \& Bharadwaj, L. (2016). Combining western and traditional knowledge in the northwest territories. Water Canada. Retrieved from http://watercanada.net/2016/combining-western-andtraditional-knowledge-in-the-northwest-territories/

Braune, B., Muir, D., DeMarch, B., Gamberg, M., Poole, K., Currie, R., ... Shutt, L. (1999). Spatial and temporal trends of contaminants in Canadian Arctic freshwater and terrestrial ecosystems: A review. Science of the Total Environment, 230, 145-207.

Brook, R. K., \& McLachlan, S. M. (2008). Trends and prospects for local knowledge in ecological and conservation research and monitoring. Biodiversity and Conservation, 17, 3501-3512.

Brown, R. S., Hubert, W. A., \& Daly, S. F. (2011). A primer on winter, ice, and fish: What fisheries biologists should know about winter ice processes and stream-dwelling fish. Fisheries, 36, 8-26.

Canadian Water Network. (2015). Slave River and Slave River delta node. Retrieved February 18, 2016 from http://www.cwn-rce.ca/focus-areas/canadian-watershed-research-consortium/slave-river-andslave-river-delta-node/

Carr, M. K., Jardine, T. D., Doig, L. E., Jones, P. D., Bharadwaj, L., Tendler,..., Lindenschmidt, K.-E. (2017). Stable sulfur isotopes identify habitat-specific foraging and mercury exposure in a highly mobile fish community. Science of the Total Environment, 586, 338-346.

Centre for Aboriginal Culture and Education. (n.d.). Guidelines for working with first nations, inuit, and Métis elders. Retrieved March 1, 2016, from http://carleton.ca/aboriginal/wp-content/uploads/ Guidelines-for-Working-with-Elders.pdf

Collings, P., Marten, M. G., Pearce, T., \& Young, A. G. (2016). Country food sharing networks, household structure, and implications for understanding food insecurity in Arctic Canada. Ecology of Food and Nutrition, 55, 30-49.

Council on Aboriginal Initiatives. (2012). Elder protocol and guidelines. Retrieved March 1, 2016, from http://www.provost.ualberta.ca/ /media/provost/Documents/CAl/Elders.pdf

Culp, J. M., Cash, K. J., \& Wrona, F. J. (2000). Cumulative effects assessment for the Northern River Basins Study. Journal of Aquatic Ecosystem Stress and Recovery, 8, 87-94.

Dei, G. J. S. (2000). Rethinking the role of indigenous knowledges in the academy. International Journal of Inclusive Education, 4, 111-132.

DFO. (2013). Assessment of Buffalo River inconnu (Stenodus leucichthys) Great Slave Lake, Northwest Territories, 1945-2009 (DFO Can. Sci. Advis. Sec. Sci. Advis. Rep. 2012/045).

Doig, L., Meissner, A. G. N., Carr, M. K., Jardine, T. D., Jones, P. D., Bharadwaj, L., \& Lindenschmidt, K.-E. (submitted). Seasonal physicochemical associations of mercury and various trace elements in bottom sediments of a northern freshwater deltaic system. Science of the Total Environment.

Donaldson, S. G., Van Oostdam, J., Tikhonov, C., Feeley, M., Armstrong, B., Ayotte, P., ...Shearer, R. G. (2010). Environmental contaminants and human health in the Canadian Arctic. Science of the Total Environment, 408, 5165-5234.

English, M. C., Hill, B., Stone, M. A., \& Ormson, R. (1997). Geomorphological and botanical change on the outer Slave River Delta, NWT, before and after impoundment of the Peace River. Hydrological Processes, 11, 1707-1727.

English, M. C., Stone, M. A., Hill, B., Wolfe, P. M., \& Ormson, R. (1996) Assessment of impacts on the Slave River Delta of the Peace River impoundment at Hudson Hope (Northern River Basins Study Synthesis Report No. 13). Edmonton, Alberta. Retrieved December 9, 2016, from http://www.barbau.ca/ content/northern-river-basins-study-project

Environment Canada. (2015). Canadian climate normals 1981-2010 station data. Retrieved March 3, 2016, from http://climate.weather.gc.ca/climate_normals/results_1981_2010_e.html?stnID=1660\& lang $=$ e\&StationName $=$ Fort + smith $\&$ SearchType $=$ Contains $\&$ stnNameSubmit $=$ go\&dCode $=1 \&$ dispBack=1

Failing, L., Gregory, R., \& Harstone, M. (2007). Integrating science and local knowledge in environmental risk management: A decision-focused approach. Ecological Economics, 64, 47-60. 
Freeman, M. M. R. (1992). The nature and utility of traditional ecological knowledge. Northern Perspectives, 20, 9-12. http://www.carc.org/pubs/v20no1/utility.htm

Gallagher, C. (2003). Quit thinking like a scientist! pages. In J. Oakes, R. Riewe, A. Edmunds, A. Dubois, \& K. Wilde (Eds.), Native voices in research (pp. 183-190). Winnipeg, Canada: Aboriginal Issues Press.

Gharabaghi, B., Inkratas, C., Beltaos, S., \& Krishnappan, B. (2007). Modelling of three dimensional flow velocities in a deep hole in the East Channel of the Mackenzie Delta, Northwest Territories. Canadian Journal of Civil Engineering, 34, 1312-1323.

Houde, N. (2007). The six faces of traditional ecological knowledge: challenges and opportunities for Canadian co-management arrangements. Ecology and Society, 12, 34. Retrieved from http://www. ecologyandsociety.org/vol12/iss2/art34/

Howland, K. L., Tallman, R. F., \& Tonn, W. M. (2000). Migration patterns of freshwater and anadromous inconnu in the Mackenzie River System. Transactions of the American Fisheries Society, 129, 41-59.

Iseke-Barnes, J. (2003). Living and writing indigenous spiritual resistance. Journal of Intercultural Studies, 24, 211-238.

Leys, A. J., \& Vanclay, J. K. (2011). Social learning: A knowledge and capacity building approach for adaptive co-management of contested landscapes. Land Use Policy, 28, 574-584.

Little, A. S. (1997). Food and habitat use within the fish assemblages of the lower Slave River, Northwest Territories (Master's thesis). University of Alberta. Retrieved February 17, 2016, from http://www. collectionscanada.gc.ca/obj/s4/f2/dsk2/ftp04/mq21185.pdf

Little, A. S., Tonn, W. M., Tallman, R. F., \& Reist, J. D. (1998). Seasonal variation in diet and trophic relationships within the fish communities of the lower Slave River, Northwest Territories, Canada. Environmental Biology of Fishes, 53, 429-445.

Lockhart, W. L., Stern, G. A., Low, G., Hendzel, M., Boila, G., Roach, P., ...DeGraff, N. (2005). A history of total mercury in edible muscle of fish from lakes in northern Canada. Science of the Total Environment, 351, 427-463.

Mackenzie River Basin Board. (2004). Mackenzie River Basin: State of the aquatic ecosystem report 2003. NT: Fort Smith.

Mazzocchi, F. (2006). Western science and traditional knowledge. EMBO reports. Retrieved February 16, 2016, from http://www.ncbi.nlm.nih.gov/pmc/articles/PMC1479546/pdf/7400693.pdf

Melnychuk, N., Jatel, N., \&Warwick Sears, A. L. (2016). Integrated water resource management and British Columbia's Okanagan Basin Water Board. International Journal of Water Resources Development, doi:10.1080/07900627.2016.1214909

Mollard, J.D. (1981). Slave River delta interpretative explanation. In Slave River Delta. Mackenzie River basin Study Report Supplement 6. Prepared for the Mackenzie River Basin Committee, Ottawa, ON.

Nakano, T., Fediuk, K., Kassi, N., \& Kuhnlein, H. V. (2005). Food use of Dene/Metis and Yukon children. International Journal of Circumpolar Health, 64(2), 137-146.

Nakashima, D. J., \& Roué, M. (2002). Indigenous knowledge, peoples and sustainable practice. In P. Timmerman (Ed.), Encyclopedia of global environmental change.5: Social and economic dimensions of global environmental change (pp. 314-324). Chichester, UK: Wiley.

Nash, H. L. (2014). Defining appropriate spatial and temporal scales for ecological impact analysis. Environmental Practice, 16, 281-286.

Native Science. (n.d.). Comparisons between traditional \& scientific knowledge. Retrieved February 16, 2016, from http://www.nativescience.org/html/traditional_and_scientific.html

Ohiozebau, E., Tendler, B., Hill, A., Codling, G., Kelly, E., Giesy, J. P., \& Jones, P. D. (2016). Products of biotransformation of polycylic aromatic hydrocarbons in fishes of the Athabasca/Slave river system, Canada. Environmental Geochemistry and Health, 38, 577-591.

Pembina Institute. (2016). State of the knowledge of the Slave River and Slave River Delta. Prepared for the Slave River and Delta Partnership. Retrieved June 16, 201, from http://www.nwtwaterstewardship. ca/sites/default/files/FINAL_APRIL'16_FINAL_Slave\%20River\%20State\%20of\%20the\%20 Knowledge\%20Report.pdf

Rathwell, K., Armitage, D., \& Berkes, F. (2015). Bridging knowledge systems to enhance governance of environmental commons: A typology of settings. International Journal of the Commons, 9, 851-880.

Rioux, S., Savard, J.-P. L., \& Gerick, A. A. (2013). Avian mortalities due to transmission line collisions: A review of current estimates and field methods with an emphasis on applications to the Canadian 
electric network. Avian Conservation and Ecology, 8, 7. Retrieved from http://dx.doi.org/10.5751/ ACE-00614-080207

Schauder, D. (1994). Electronic publishing of professional articles: Attitudes of academics and implications for the scholarly communication industry. Journal of the American Society for Information Science, 45, 73-100.

Scott, W. B., \& Crossman, E. J. (1973). Freshwater Fishes of Canada Bulletin 184. Ottawa: Fish. Res. Board of Canada.

Sheehy, T., Kolahdooz, F., Schaefer, S. E., Douglas, D. N., Corriveau, A., \& Sharma, S. (2015). Traditional food patterns are associated with better diet quality and improved dietary adequacy in Aboriginal peoples in the Northwest Territories, Canada. Journal of Human Nutrition and Dietetics, 28, 262-271.

Smith, H. A., \& Sharp, K. (2012). Indigenous climate knowledges. Wiley Interdisciplinary Reviews: Climate Change, 3, 467-476.

Stewart, D. B. (1999). A review of information on fish stocks and harvests in the South Slave Area, Northwest Territories. Retrieved February 20, 2016, from http://www.dfo-mpo.gc.ca/Library/251225.pdf

Sutherland, W. J., Gardner, T. A., Haider, L. J., \& Dicks, L. V. (2014). How can local and traditional knowledge be effectively incorporated into international assessments? Oryx, 48, 1-2.

Tallman, R. F. (1996). Synthesis of fish distribution, movements, critical habitat and food web for the lower Slave River north of the 60th parallel: A food chain perspective (Northern River Basins Study Synthesis Report No. 13). Edmonton, Alberta. Retrieved February 20, 2016, from http://www.publications. gc.ca/site/eng/61045/publication.html

Tallman, R. F., Howland, K. L., Low, G., Tonn, W. M., \& Little, A. (2005). Composition and changes to the fish assemblage in a large sub-arctic drainage: The Lower Slave River. In J.N. Rinne, R.M. Hughes, \& B. Calamusso (Eds.), Historical changes in large river fish assemblages of the Americas, American Fisheries Society Symposium (Vol. 45, pp. 23-39). Bethesda, Maryland: American Fisheries Society.

Tallman, R. F., Tonn, W. M., \& Howland, K. L. (1996a). Migration of inconnu (Stenodus leucichthys) and burbot (Lota lota), Slave River and Great Slave Lake, June, 1994 to July, 1995 (Northern River Basins Study Project Report No. 117). Edmonton, Alberta.

Tallman, R. F., Tonn, W. M., \& Howland, K. L. (1996b). Life history variation of inconnu (Stenodus leucicthys) and burbot (Lota lota), Lower Slave River, June to December, 1994 (Northern River Basins Study Project Report No. 118). Edmonton, Alberta.

Tallman, R. F., Tonn, W. M., \& Little, A. S. (1996c). Diet, food web and structure of the fish community, lower Slave River, June to December, 1994 and May to August, 1995 (Northern River Basins Study Project Report No. 119). Edmonton, Alberta. Retrieved February 18, 2016, from http://www.publications. gc.ca/site/eng/60984/publication.html

Tripp, D. B., McCart, P. J., Saunders, R. D., \& Hughes, G. W. (1981). Fisheries studies in the Slave River delta, NWT (Final Reportln Mackenzie River Basin Study, Suppl. 6. Prepared for Joint Federal-Provincial Mackenzie River Basin Committee). 262 pp.

Usher, P. J. (2000). Traditional ecological knowledge in environmental assessment and management. Arctic, 53, 183-193.

Vanderburgh, S., \& Smith, D. G. (1988). Slave River delta: Geomorphology, sedimentology, and Holocene reconstruction. Canadian Journal of Earth Sciences, 25, 1990-2004.

Wein, E. E., \& Freeman, M. M. R. (1995). Frequency of traditional food use by three Yukon First Nations living in four communities. Arctic, 48, 161-171.

Wein, E. E., \& Wein, R. W. (1995). Predictions of global warming influences on aboriginal food-use patterns in Northwestern Canada. Northern Review, 14, 86-94.

Wolfe, B. B., Armitage, D., Wesche, S., Brock, B. E., Sokal, M. A., Clogg-Wright, K. P., ... Edwards, T.W.D. (2007). From isotopes to TK interviews: Towards interdisciplinary research in Fort Resolution and the Slave River Delta, Northwest Territories. Arctic, 60, 75-87.

Working Group on General Status of NWT Species. (2011). NWT species 2011-2015-General status ranks of wild species in the Northwest territories (p. 172). Yellowknife, NT: Department of Environment and Natural Resources, Government of the Northwest Territories. 


\section{Ecological patterns of fish distribution in the Slave River Delta region, Northwest Territories, Canada, as relayed by Traditional Knowledge and Western science}

Cara Baldwin, Lori Bradford, Meghan K. Carr, Lorne E. Doig, Timothy D. Jardine, Paul D. Jones, Lalita Bharadwaj \& Karl-Erich Lindenschmidt

To cite this article: Cara Baldwin, Lori Bradford, Meghan K. Carr, Lorne E. Doig, Timothy D. Jardine, Paul D. Jones, Lalita Bharadwaj \& Karl-Erich Lindenschmidt (2017): Ecological patterns of fish distribution in the Slave River Delta region, Northwest Territories, Canada, as relayed by Traditional Knowledge and Western science, International Journal of Water Resources Development, DOI: 10.1080/07900627.2017.1298516

To link to this article: http://dx.doi.org/10.1080/07900627.2017.1298516

+ View supplementary material 준

Submit your article to this journal $₫$
Published online: 24 Mar 2017.

山 Article views: 59 